\title{
Effect of Drip Fertigation on Dry Matter Production and Nitrogen Use Efficiency of Maize (Zea mays)
}

\author{
Raja Kumar $^{1 *}$, A. Mani ${ }^{1}$, G. Ravi Babu ${ }^{2}$, M. Martin Luther ${ }^{3}$ and CH. Sujani Rao ${ }^{4}$ \\ ${ }^{1}$ Department of Soil and Water Conservation Engineering, Dr. NTR College of Agricultural \\ Engineering, ANGRAU, Bapatla, India \\ ${ }^{2}$ College of Agricultural Engineering, ANGRAU, Madakasira, India \\ ${ }^{3}$ Dept. of Agronomy, Agricultural College, Bapatla, India \\ ${ }^{4}$ Controller of Examinations, Administrative Office Lam, Guntur, India \\ *Corresponding author
}

\section{Keywords}

Maize crop, Drip fertigation, Dry matter production, Nitrogen use efficiency

\section{Article Info}

Accepted:

20 December 2020

Available Online:

10 January 2021

\section{A B S T R A C T}

Maize crop requires number of macro-nutrients and micro-nutrients for its growth and development. Nitrogen is one of the key nutrients needed for crop production; however, it is the most mobile and volatile and mainly exhausted nutrients due to its ability to exist in unusual forms and its easy leach ability. Lack of knowledge among the maize growers about the consequences of irrational use of water and nitrogen is mainly responsible for low water use efficiency and nitrogen use efficiency at field level. A field experiment was conducted during kharif, 2018 and rabi, 2019 under maize crop at the field irrigation laboratory, Department of Soil and Water Engineering, Dr. N. T. R. College of Agricultural Engineering, Bapatla, Guntur district of Andhra Pradesh State, India. The rainfall received during crop growing period of kharif 2018 was $303.4 \mathrm{~mm}$ and $69.1 \mathrm{~mm}$ during rabi, 2018-19. The initial soil physical and chemical properties of the experiment site were calculated. The inline drip irrigation system was designed in split pot for the experiment with three irrigation levels (main plots) namely $\mathrm{I}_{1}=0.6$ of the crop evapotranspiration, $\mathrm{I}_{2}=0.8$ of the crop evapotranspiration and $\mathrm{I}_{3}=1.0$ of the crop evapotranspiration and four nitrogen levels ( sub plots) namely $\mathrm{N}_{1}=$ Drip fertigation with $80 \%$ of recommended dose of nitrogen $(\mathrm{CF}), \mathrm{N}_{2}=$ Drip fertigation with $100 \%$ of recommended dose of nitrogen (CF), $\mathrm{N}_{3}=$ Drip fertigation with $120 \%$ of recommended dose of nitrogen (CF) and $\mathrm{N}_{4}=$ No drip fertigation (manual application) with $100 \%$ of recommended dose of nitrogen (CF) with three replications. The amount of crop water requirement of maize was estimated with computer software CROPWAT (v 8.0). The dry matter production (DMP) and nitrogen use efficiency (NUF) of maize were estimated for both the seasons. The results shown that during kharif 2018 the highest value of DMP was found in $\mathrm{I}_{3}$ treatment ( $399.22 \mathrm{~kg} \mathrm{ha}^{-1}$ ) followed by $\mathrm{I}_{2}$ and $\mathrm{I}_{1}$ treatments (392.93 and 381.90 $\left.\mathrm{kg} \mathrm{ha}^{-1}\right)$. During rabi 2018-19, the value of DMP was found in $\mathrm{I}_{3}$ treatment $\left(574.62 \mathrm{~kg} \mathrm{ha}^{-}\right.$ ${ }^{1}$ ) followed by $I_{2}$ and $I_{1}$ treatments ( 565.29 and $446.38 \mathrm{~kg} \mathrm{ha}^{-1}$ ). The highest NUE of 32.88 $\mathrm{kg} \mathrm{ha}^{-1} \mathrm{~mm}^{-1}$ was obtained in $\mathrm{I}_{2} \mathrm{~N}_{1}$ treatment during kharif 2018. During rabi 2018-19, the highest NUE of $32.85 \mathrm{~kg} \mathrm{ha}^{-1} \mathrm{~mm}^{-1}$ was in $\mathrm{I}_{2} \mathrm{~N}_{2}$. The lowest NUE of 21.35 and $22.36 \mathrm{~kg}$ ha ${ }^{-1} \mathrm{~mm}^{-1}$ was obtained in $\mathrm{I}_{1} \mathrm{~N}_{3}$ treatment during kharif 2018 and rabi 2018-19. 


\section{Introduction}

Maize (Zea mays) well known as Queen of grains, also called corn from Graminae family. Maize can be grown on a variety of soils ranging from sandy to clay. But it performs best on well drained, aerated deeploams and silt loams containing organic matter and nutrients. Maize may be raised on moderately acid soils, but the optimum $\mathrm{pH}$ range is from 6.5 to 7.5. Highly saline, acidic, alkaline and water logged soils should be avoided. The crop is cultivated in $9.47 \mathrm{M}$ ha area with 28.72 Million Tonnes of production, $3030 \mathrm{~kg}$ per hectare productivity during 201718 (Source: Agricultural Statistics at a glance 2018).

Maize crop requires number of macronutrients and micro-nutrients for its growth and development. Nitrogen is one of the key nutrients needed for crop production; however, it is the most mobile and volatile and mainly exhausted nutrients due to its ability to exist in unusual forms and its easy leach ability (Palm et al., 1997; Mugendi et al., 2007; Mucheru-Muna et al., 2014). Among several functions, nitrogen plays a key role on maize plants metabolism. Lack of knowledge among the maize growers about the consequences of irrational use of water and nitrogen is mainly responsible for low water use efficiency and nitrogen use efficiency at field level. The excess use and uneven application of irrigation and fertilizer application elevates the cost of cultivation and contributes to dreadful conditions of the water and soil quality. Therefore, there is an urgent need of efficient and judicious application of water resources and nutrients for sustainability of maize production.

\section{Materials and Methods}

Field experiments was conducted during kharif, 2018 and rabi, 2018-19 under maize crop at Field irrigation laboratory, Department of Soil and Water Engineering, Dr. N. T. R. College of Agricultural Engineering, Bapatla, Guntur district of Andhra Pradesh State, India. Geographically the experimental site is located at latitude of $16^{\circ} \mathrm{N}$ and longitude of $88^{\circ} \mathrm{E}$ with an altitude of $6 \mathrm{~m}$ above mean sea level. The rainfall received during crop growing period was $303.4 \mathrm{~mm}$ during kharif, 2018 and $69.1 \mathrm{~mm}$ during rabi, 2018-19. Soil samples were collected at every $15 \mathrm{~cm}$ layers from land surface till the soil depth of $90 \mathrm{~cm}$ using soil augur to characterize the soil. The collected soil samples were analysed in laboratory at Agricultural college, Bapatla for determining the physical properties of the soil such as Textural class, Hydraulic conductivity $(\mathrm{cm} / \mathrm{h})$, Bulk density, Field capacity, permanent wilting point and chemical properties like $\mathrm{pH}$, EC, organic carbon and available nitrogen, phosphorous and potassium were shown in Table $1 \& 2$.

A drip irrigation system was designed for the experiment under maize crop. The lateral lines were spaced at $1.2 \mathrm{~m}$ interval. Inline drip emitters with $2.0 \mathrm{lph}$ rated discharge were placed on the lateral line at a spacing of 30 $\mathrm{cm}$. Each plot comprises three laterals with a spacing of $1.2 \mathrm{~m}$ distance with a net plot size of $8.0 \times 3.6 \mathrm{~m}\left(28.8 \mathrm{~m}^{2}\right)$. A total of 36 plots were designed. A control valve was provided to each plot to regulate the operation of irrigation.

Experiments were conducted with DEKALB DKC 8161 variety of hybrid maize under drip irrigation in split plot design consisting of three irrigation levels (main plots) namely $\mathrm{I}_{1}=$ 0.6 of the crop evapotranspiration, $\mathrm{I}_{2}=0.8$ of the crop evapotranspiration and $I_{3}=1.0$ of the crop evapotranspiration and four nitrogen levels ( sub plots) namely $\mathrm{N}_{1}=$ Drip fertigation with $80 \%$ of recommended dose of nitrogen $(\mathrm{CF}), \mathrm{N}_{2}=$ Drip fertigation with 
$100 \%$ of recommended dose of nitrogen $(\mathrm{CF})$, $\mathrm{N}_{3}=$ Drip fertigation with $120 \%$ of recommended dose of nitrogen $(\mathrm{CF})$ and $\mathrm{N}_{4}=$ No drip fertigation (manual application) with $100 \%$ of recommended dose of nitrogen (CF) with three replications.

Treatment wise requirement of $\mathrm{N}, \mathrm{P}$ and $\mathrm{K}$ were estimated. $\mathrm{P}$ was applied as basal application manually and the $50 \%$ of $\mathrm{K}$ was applied in basal at the time of sowing and remaining $50 \%$ of $\mathrm{K}$ was applied at flowering stage manually. To optimize the fertigation scheduling, the estimated quantity of $\mathrm{N}$ for selected treatments was applied through venturi under drip fertigation at every 10 days interval.

The dry matter production and nitrogen use efficiency of maize were estimated for both the seasons. The statistical tool SPSS (v16.0) was used to find out the significance difference between the treatment means. One way ANOVA technique was used to compare the treatment means of dry matter production (DMP) and WUE at 5\% level of significance. The Duncan Multiple Range Test (DMRT) was performed to find the significant grouping between means of DMP and NUE.

\section{Results and Discussion}

\section{Effect of drip fertigation on dry matter production of maize}

The observations recorded on dry matter production of maize at harvest stage are shown in Table 3 and depicting in Fig 1. During kharif 2018, the dry matter production of maize was found to be significantly influenced by both irrigation as well as fertigation levels. The results shown that highest value of DMP was found in $\mathrm{I}_{3}$ treatment $\left(399.22 \mathrm{~kg} \mathrm{ha}^{-1}\right)$ followed by $\mathrm{I}_{2}$ and $\mathrm{I}_{1}$ treatments $\left(392.93\right.$ and $\left.381.90 \mathrm{~kg} \mathrm{ha}^{-1}\right)$.
The analysis of variance to compare the means of DMP (Table. 4) for kharif 2018 showed that there is a significant difference between irrigation levels $(P=0.000)$. In case of nitrogen levels, DMP of $399.22 \mathrm{~kg} \mathrm{ha}^{-1}$ was produced by $\mathrm{N}_{3}$ treatment followed by $\mathrm{N}_{2}, \mathrm{~N}_{4}$ and $\mathrm{N}_{1}$. The analysis of variance to compare the means of DMP (Table. 4) showed that there is a significant difference between nitrogen levels $(\mathrm{P}=0.000)$.

The Duncan test (Table $5 \&$ 6) for comparing treatment means for main plots (Irrigation levels) of DMP at harvest stage showed that $I_{1}$ treatment has significant difference, whereas $\mathrm{I}_{2}$ and $\mathrm{I}_{3}$ have on par effect. Duncan test for comparing treatment means for nitrogen plots of DMP at harvest stage showed that $\mathrm{N}_{1}$ treatment has significant difference, whereas $\mathrm{N}_{4}, \mathrm{~N}_{2}$ and $\mathrm{N}_{2}, \mathrm{~N}_{3}$ have on par effect. The interaction effect between irrigation and fertigation levels had influenced the DMP ( $\mathrm{P}$ $=0.041)$ at harvest stage.

During rabi 2018-19, the dry matter production of maize was found to be significantly influenced by both irrigation as well as fertigation levels. The results shown that highest value of DMP was found in $\mathrm{I}_{3}$ treatment $\left(574.62 \mathrm{~kg} \mathrm{ha}^{-1}\right)$ followed by $\mathrm{I}_{2}$ and $\mathrm{I}_{1}$ treatments $\left(565.29\right.$ and $446.38 \mathrm{~kg} \mathrm{ha}^{-1}$ ). The analysis of variance to compare the means of DMP (Table. 4) for rabi 2018 showed that there is a significant difference between irrigation levels $(P=0.000)$. In case of nitrogen levels, highest DMP of $574.62 \mathrm{~kg}$ ha ${ }^{1}$ was produced by $\mathrm{N}_{3}$ treatment followed by $\mathrm{N}_{2}, \mathrm{~N}_{4}$ and $\mathrm{N}_{1}$. The analysis of variance to compare the means of DMP (Table. 4) showed that there is a significant difference between nitrogen levels $(\mathrm{P}=0.000)$.

The Duncan test (Table $7 \&$ 8) for comparing treatment means for main plots (Irrigation levels) of DMP at harvest stage showed that $\mathrm{I}_{1}$ treatment has significant difference, whereas 
$I_{2}$ and $I_{3}$ had on par effect. The Duncan test for comparing treatment means for nitrogen plots of DMP at harvest stage showed that $\mathrm{N}_{4}$, $\mathrm{N}_{1}$ and $\mathrm{N}_{2}, \mathrm{~N}_{3}$ treatment had on par effect. The interaction effect between irrigation and fertigation levels had not influenced the DMP $(\mathrm{P}=0.547)$ at harvest stage.

As the native soil was low in nitrogen, there was a good response to the excess fertilizer applied, coupled with optimum moisture availability which might have resulted in inducing growth. Rajasekaran (2007) reported higher DMP under 125 per cent RDF followed by 100 per cent in drip irrigated sugar beet. Bar-Yosef et al., (1989) reported that subsurface fertigation hastened dry matter accumulation and affected carbohydrate partitioning between plant organs in a way that contributed to higher ear yield in corn. Vadivel et al., (2001) and Singh and Sharma (1994) reported higher LAI and DMP when N rate was increased in maize.

Better growth of maize under drip might be attributed to better moisture availability, soil aeration and also crop did not experience stress during the crop growth period at 1.0 PE irrigation schedule.

This ultimately reflected better physiological activity in plant and there by increased plant height, and dry matter production per plant. Similarly findings were reported by Patel et al., (2006), Bindhani et al., (2008), Ganesaraja et al., (2009), Muthukrishnan et al., (2011), Mallareddy et al., (2012) and Bibe et al., (2017).

Table.1 Physical properties of the experimental soil

\begin{tabular}{|c|c|c|c|c|c|c|c|c|}
\hline \multirow{2}{*}{$\begin{array}{l}\text { Soil depth } \\
\text { from } \\
\text { surface } \\
\text { (cm) }\end{array}$} & \multicolumn{3}{|c|}{$\begin{array}{c}\text { Mineral content } \\
\% \text { mass }\end{array}$} & \multirow[t]{2}{*}{ Textural class } & \multirow{2}{*}{$\begin{array}{l}\text { Hydraulic } \\
\text { conductivity } \\
\left(\mathrm{cm} \mathrm{h}^{-1}\right)\end{array}$} & \multirow{2}{*}{$\begin{array}{c}\text { Bulk } \\
\text { density } \\
\left(\mathrm{g} / \mathrm{cm}^{3}\right)\end{array}$} & \multirow{2}{*}{$\begin{array}{c}\text { Field } \\
\text { capacity } \\
(\% \text { vol })\end{array}$} & \multirow{2}{*}{$\begin{array}{c}\text { Permanent } \\
\text { wilting point } \\
\text { (\% vol) }\end{array}$} \\
\hline & Clay & Silt & Sand & & & & & \\
\hline $0-15$ & 35 & 10 & 55 & Sandy clay loam & 0.94 & 1.37 & 21.48 & 6.73 \\
\hline $15-30$ & 35 & 10 & 55 & Sandy clay loam & 0.50 & 1.57 & 27.17 & 9.12 \\
\hline $30-45$ & 40 & 10 & 60 & Sandy clay & 0.46 & 1.53 & 28.24 & 10.56 \\
\hline $45-60$ & 35 & 5 & 60 & Sandy clay loam & 0.96 & 1.63 & 27.69 & 10.92 \\
\hline $60-75$ & 35 & 5 & 60 & Sandy clay loam & 0.96 & 1.63 & 27.73 & 11.61 \\
\hline $75-90$ & 30 & 5 & 65 & Sandy clay loam & 0.95 & 1.67 & 26.62 & 10.75 \\
\hline
\end{tabular}

Table.2 Chemical properties of the experimental soil

\begin{tabular}{|c|c|c|c|c|c|c|}
\hline \multirow{2}{*}{$\begin{array}{l}\text { Soil depth from } \\
\text { surface }(\mathrm{cm})\end{array}$} & \multirow[t]{2}{*}{$\mathbf{P}^{\mathbf{H}}$} & \multirow{2}{*}{$\begin{array}{c}\mathrm{EC} \\
\left(\mathrm{ds} \mathrm{\textrm {m } ^ { - 1 }}\right)\end{array}$} & \multirow{2}{*}{$\begin{array}{c}\text { Organic } \\
\text { carbon } \\
(\%)\end{array}$} & \multicolumn{3}{|c|}{ Available } \\
\hline & & & & $\mathbf{N}\left(\mathrm{Kg} \mathrm{ha}^{-1}\right)$ & P $\left(\mathrm{Kg} \mathrm{ha}^{-1}\right)$ & $\mathrm{K}\left(\mathrm{Kg} \mathrm{ha}^{-1}\right)$ \\
\hline $0-15$ & 5.62 & 0.10 & 0.27 & 141.12 & 28.21 & 141.12 \\
\hline $15-30$ & 6.86 & 0.16 & 0.12 & 147.39 & 34.88 & 87.36 \\
\hline $30-45$ & 7.05 & 0.20 & 0.10 & 119.16 & 21.03 & 87.36 \\
\hline $45-60$ & 5.34 & 0.11 & 0.09 & 56.44 & 13.33 & 53.76 \\
\hline $60-75$ & 5.14 & 0.05 & 0.075 & 40.76 & 12.82 & 53.76 \\
\hline $75-90$ & 5.42 & 0.03 & 0.06 & 25.08 & 11.28 & 47.07 \\
\hline
\end{tabular}


Table.3 Effect of drip fertigation on dry matter production $\left(\mathrm{kg} \mathrm{ha}^{-1}\right)$

\begin{tabular}{|c|c|c|}
\hline \multirow{2}{*}{ Treatment } & \multicolumn{2}{|c|}{ Dry matter production $\left(\mathbf{k g ~ h a}^{\mathbf{- 1}}\right)$} \\
\cline { 2 - 3 } & Kharif 2018 & Rabi 2018 \\
\hline I1N1 & 344.37 & 404.55 \\
\hline I1N2 & 375.97 & 440.02 \\
\hline I1N3 & 381.90 & 446.38 \\
\hline I1N4 & 370.10 & 379.86 \\
\hline I2N1 & 382.77 & 528.58 \\
\hline I2N2 & 392.93 & 555.57 \\
\hline I2N3 & 392.21 & 569.86 \\
\hline I2N4 & 388.85 & 536.92 \\
\hline I3N1 & 381.76 & 536.03 \\
\hline I3N2 & 397.66 & 565.29 \\
\hline I3N3 & 399.22 & 574.62 \\
\hline I3N4 & 389.73 & 538.17 \\
\hline
\end{tabular}

Table.4 Univariate Analysis of Variance to compare the means of dry matter production

\begin{tabular}{|c|c|c|c|c|c|}
\hline \multicolumn{7}{|c|}{ Kharif 2018} \\
\hline Source & $\begin{array}{c}\text { Type III Sum of } \\
\text { Squares }\end{array}$ & df & Mean Square & F & Sig. \\
\hline MAIN & 4121.002 & 2 & 2060.501 & 47.845 & .000 \\
\hline SUB & 2508.090 & 3 & 836.030 & 19.413 & .000 \\
\hline MAIN * SUB & 726.421 & 6 & 121.070 & 2.811 & .041 \\
\hline Total & 7355.513 & 11 & & \\
\hline a. R Squared = .910 (Adjusted R Squared = .824) \\
\hline \multicolumn{7}{|c|}{ Rabi 2018-19 } \\
\hline MAIN & 141560.198 & 2 & 70780.099 & 206.788 & .000 \\
\hline SUB & 13503.058 & 3 & 4501.019 & 13.150 & .000 \\
\hline MAIN * SUB & 1751.711 & 6 & 291.952 & .853 & .547 \\
\hline \multicolumn{2}{|c|}{ Total } & 156814.97 & 11 & & \\
\hline a. R Squared = .963 (Adjusted R Squared = .928) \\
\hline
\end{tabular}

Table.5 Duncan test for comparing treatment means for main plots (Irrigation levels) of Dry matter production for kharif 2018

\begin{tabular}{|c|c|c|c|}
\hline Main plots & $\mathbf{N}$ & \multicolumn{2}{|c|}{ Subject for alpha 0.05 } \\
\cline { 3 - 4 } & & $\mathbf{1}$ & $\mathbf{2}$ \\
\hline $\mathbf{I}_{\mathbf{1}}$ & 12 & $3.6809 \mathrm{E} 2$ & $3.8919 \mathrm{E} 2$ \\
\hline $\mathbf{I}_{\mathbf{2}}$ & 12 & & $3.9209 \mathrm{E} 2$ \\
\hline $\mathbf{I}_{\mathbf{3}}$ & 12 & 1.000 & 0.293 \\
\hline Sig. & \multicolumn{3}{|l|}{} \\
\hline $\begin{array}{l}\text { Means for groups in homogeneous subsets are displayed. } \\
\text { Based on observed means. } \\
\text { The error term is Mean Square(Error) }=\mathbf{4 3 . 0 6 6 .}\end{array}$ \\
\hline
\end{tabular}


Table.6 Duncan test for comparing treatment means for sub plots ((Nitrogen levels) of Dry matter production for kharif 2018

\begin{tabular}{|c|c|c|c|c|}
\hline \multirow[t]{2}{*}{ Sub plots } & \multirow[t]{2}{*}{$\mathbf{N}$} & \multicolumn{3}{|c|}{ Subject for alpha 0.05} \\
\hline & & 1 & 2 & 3 \\
\hline $\mathbf{N}_{1}$ & 9 & $3.6963 \mathrm{E} 2$ & & \\
\hline $\mathbf{N}_{4}$ & 9 & & $3.8290 \mathrm{E} 2$ & \\
\hline $\mathbf{N}_{2}$ & 9 & & $3.8885 \mathrm{E} 2$ & $3.8885 \mathrm{E} 2$ \\
\hline $\mathbf{N}_{3}$ & 9 & & & $3.9111 \mathrm{E} 2$ \\
\hline Sig. & & 1.000 & .070 & 0.476 \\
\hline \multicolumn{5}{|c|}{$\begin{array}{l}\text { Means for groups in homogeneous subsets are displayed. } \\
\text { Based on observed means. } \\
\text { The error term is Mean Square(Error) }=43.066 \text {. }\end{array}$} \\
\hline
\end{tabular}

Table.7 Duncan test for comparing treatment means for main plots (Irrigation levels) of Dry matter production for Rabi 2018

\begin{tabular}{|c|c|c|c|}
\hline \multirow[t]{2}{*}{ Main plots } & \multirow[t]{2}{*}{$\mathbf{N}$} & \multicolumn{2}{|c|}{ Subject for alpha 0.05} \\
\hline & & 1 & 2 \\
\hline $\mathbf{I}_{1}$ & 12 & $4.1770 \mathrm{E} 2$ & \\
\hline $\mathbf{I}_{2}$ & 12 & & $5.4773 \mathrm{E} 2$ \\
\hline $\mathbf{I}_{3}$ & 12 & & $5.5353 \mathrm{E} 2$ \\
\hline Sig. & & 1.000 & 0.453 \\
\hline
\end{tabular}

Table.8 Duncan test for comparing treatment means for sub plots (Nitrogen levels) of Dry matter production for Rabi 2018

\begin{tabular}{|c|c|c|c|}
\hline \multirow[t]{2}{*}{ Sub plots } & \multirow[t]{2}{*}{$\mathbf{N}$} & \multicolumn{2}{|c|}{ Subject for alpha 0.05} \\
\hline & & 1 & 2 \\
\hline $\mathbf{N}_{4}$ & 9 & $4.8498 \mathrm{E} 2$ & \\
\hline $\mathbf{N}_{1}$ & 9 & 4.8972E2 & \\
\hline $\mathbf{N}_{2}$ & 9 & & 5.2029E2 \\
\hline $\mathbf{N}_{3}$ & 9 & & 5.3028E2 \\
\hline Sig. & & .594 & 0.267 \\
\hline \multicolumn{4}{|c|}{$\begin{array}{l}\text { Means for groups in homogeneous subsets are displayed. } \\
\text { Based on observed means. } \\
\text { The error term is Mean Square(Error) }=\mathbf{3 4 2 . 2 8 3} \text {. }\end{array}$} \\
\hline
\end{tabular}


Table.9 Effect of drip fertigation on nutrient use efficiency during crop seasons

\begin{tabular}{|c|c|c|c|c|c|c|}
\hline \multirow{2}{*}{ Treatment } & \multicolumn{3}{|c|}{ Kharif 2018 } & \multicolumn{3}{|c|}{ Rabi 2018-19 } \\
\cline { 2 - 7 } & Yield(kg/ha) & $\begin{array}{c}\text { Amount of } \\
\text { nitrogen } \\
\text { applied(kg/ha) }\end{array}$ & $\begin{array}{c}\text { Nitrogen } \\
\text { Use } \\
\text { Efficiency }\end{array}$ & Yield(kg/ha) & $\begin{array}{c}\text { Amount of } \\
\text { nitrogen } \\
\text { applied(kg/ha) }\end{array}$ & $\begin{array}{c}\text { Nitrogen } \\
\text { Use } \\
\text { Efficiency }\end{array}$ \\
\hline I1N1 & 4408 & 144 & $\mathbf{3 0 . 6 1}$ & 4870 & 160 & $\mathbf{3 0 . 4 4}$ \\
\hline I1N2 & 4600 & 180 & $\mathbf{2 5 . 5 6}$ & 5219 & 200 & $\mathbf{2 6 . 1 0}$ \\
\hline I1N3 & 4612 & 216 & $\mathbf{2 1 . 3 5}$ & 5367 & 240 & $\mathbf{2 2 . 3 6}$ \\
\hline I1N4 & 4196 & 180 & $\mathbf{2 3 . 3 1}$ & 4986 & 200 & $\mathbf{2 4 . 9 3}$ \\
\hline I2N1 & 4734 & 144 & $\mathbf{3 2 . 8 8}$ & 5143 & 160 & $\mathbf{3 2 . 1 4}$ \\
\hline I2N2 & 5118 & 180 & $\mathbf{2 8 . 4 3}$ & 6569 & 200 & $\mathbf{3 2 . 8 5}$ \\
\hline I2N3 & 6180 & 216 & $\mathbf{2 8 . 6 1}$ & 7720 & 240 & $\mathbf{3 2 . 1 7}$ \\
\hline I2N4 & 4846 & 180 & $\mathbf{2 6 . 9 2}$ & 6170 & 200 & $\mathbf{3 0 . 8 5}$ \\
\hline 13N1 & 4621 & 144 & $\mathbf{3 2 . 0 9}$ & 5209 & 160 & $\mathbf{3 2 . 5 6}$ \\
\hline I3N2 & 5597 & 180 & $\mathbf{3 1 . 0 9}$ & 6394 & 200 & $\mathbf{3 1 . 9 7}$ \\
\hline I3N3 & 6212 & 216 & $\mathbf{2 8 . 7 6}$ & 7447 & 240 & $\mathbf{3 1 . 0 3}$ \\
\hline I3N4 & 4960 & 180 & $\mathbf{2 7 . 5 6}$ & 5903 & 200 & $\mathbf{2 9 . 5 2}$ \\
\hline
\end{tabular}

Table.10 Univariate Analysis of Variance to compare the means of nitrogen use efficiency

\begin{tabular}{|c|c|c|c|c|c|}
\hline \multicolumn{6}{|c|}{ Kharif 2018} \\
\hline Source & $\begin{array}{l}\text { Type III Sum of } \\
\text { Squares }\end{array}$ & df & Mean Square & $\mathbf{F}$ & Sig. \\
\hline MAIN & 152.991 & 2 & 76.496 & $5.077 \mathrm{E} 3$ & .000 \\
\hline SUB & 201.181 & 3 & 67.060 & $4.451 \mathrm{E} 3$ & .000 \\
\hline MAIN * SUB & 39.973 & 6 & 6.662 & 442.151 & .000 \\
\hline Total & 394.145 & 11 & & & \\
\hline \multicolumn{6}{|c|}{ a. R Squared $=.999($ Adjusted R Squared $=.999)$} \\
\hline \multicolumn{6}{|c|}{ Rabi 2018} \\
\hline MAIN & 180.762 & 2 & 90.381 & $3.252 \mathrm{E} 4$ & .000 \\
\hline SUB & 47.498 & 3 & 15.833 & $5.696 \mathrm{E} 3$ & .000 \\
\hline MAIN * SUB & 86.778 & 6 & 14.463 & $5.203 \mathrm{E} 3$ & .000 \\
\hline Total & 315.038 & 11 & & & \\
\hline
\end{tabular}

Table.11 Duncan test for comparing treatment means for main plots (Irrigation levels) of NUE for kharif 2018

\begin{tabular}{|c|c|c|c|c|}
\hline \multirow[t]{2}{*}{ Main plots } & \multirow[t]{2}{*}{$\mathbf{N}$} & \multicolumn{3}{|c|}{ Subject for alpha 0.05} \\
\hline & & 1 & 2 & 3 \\
\hline 1 & 12 & 25.2075 & & \\
\hline 2 & 12 & & 29.2100 & \\
\hline 3 & 12 & & & 29.8750 \\
\hline Sig. & 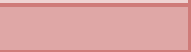 & 1.000 & 1.000 & 1.000 \\
\hline
\end{tabular}


Table.12 Duncan test for comparing treatment means for sub plots (Nitrogen levels) of NUE kharif 2018

\begin{tabular}{|c|c|c|c|c|c|}
\hline \multirow[t]{2}{*}{ Sub plots } & \multirow[t]{2}{*}{$\mathbf{N}$} & \multicolumn{4}{|c|}{ Subject for alpha 0.05} \\
\hline & & 1 & 2 & 3 & 4 \\
\hline 4 & 9 & 25.9300 & & & \\
\hline 3 & 9 & & 26.2411 & & \\
\hline 2 & 9 & & & 28.3611 & \\
\hline 1 & 9 & & & & 31.8578 \\
\hline Sig. & . & 1.000 & 1.000 & 1.000 & 1.000 \\
\hline
\end{tabular}

Table.13 Duncan test for comparing treatment means for main plots (Irrigation levels) of NUE for RABI 2018

\begin{tabular}{|l|r|r|r|r|}
\hline \multirow{2}{*}{ Main plots } & \multicolumn{1}{|c|}{$\mathbf{N}$} & \multicolumn{3}{|c|}{ Subject for alpha 0.05 } \\
\cline { 2 - 5 } & 12 & 26.9233 & & $\mathbf{3}$ \\
\hline $\mathbf{1}$ & 12 & & 31.2675 & \\
\hline $\mathbf{3}$ & 12 & & & 32.0008 \\
\hline $\mathbf{2}$ & & 1.000 & 1.000 & 1.000 \\
\hline Sig. & $\begin{array}{l}\text { Means for groups in homogeneous subsets are displayed. } \\
\text { Based on observed means. } \\
\text { The error term is Mean Square(Error) }=\mathbf{. 0 0 3}\end{array}$ \\
\hline
\end{tabular}

Table.14 Duncan test for comparing treatment means for sub plots (Nitrogen levels) of NUE RABI 2018

\begin{tabular}{|l|r|r|r|r|r|}
\hline \multirow{2}{*}{ Sub plots } & N & \multicolumn{4}{|c|}{ Subject for alpha $\mathbf{0 . 0 5}$} \\
\hline & & $\mathbf{1}$ & \multicolumn{2}{|c|}{$\mathbf{2}$} & \multicolumn{1}{|c|}{$\mathbf{3}$} \\
\hline $\mathbf{3}$ & 9 & 28.5189 & & & \\
\hline $\mathbf{4}$ & 9 & & 29.7222 & & \\
\hline $\mathbf{2}$ & 9 & & & 30.3022 & \\
\hline $\mathbf{1}$ & 9 & & & & 31.7122 \\
\hline Sig. & & 1.000 & 1.000 & 1.000 & 1.000 \\
\hline
\end{tabular}

Means for groups in homogeneous subsets are displayed.

Based on observed means.

The error term is Mean Square $($ Error $)=.003$. 
Fig.1 Effect of drip fertigation on dry matter production $\left(\mathrm{kg} \mathrm{ha}^{-1}\right)$ of maize

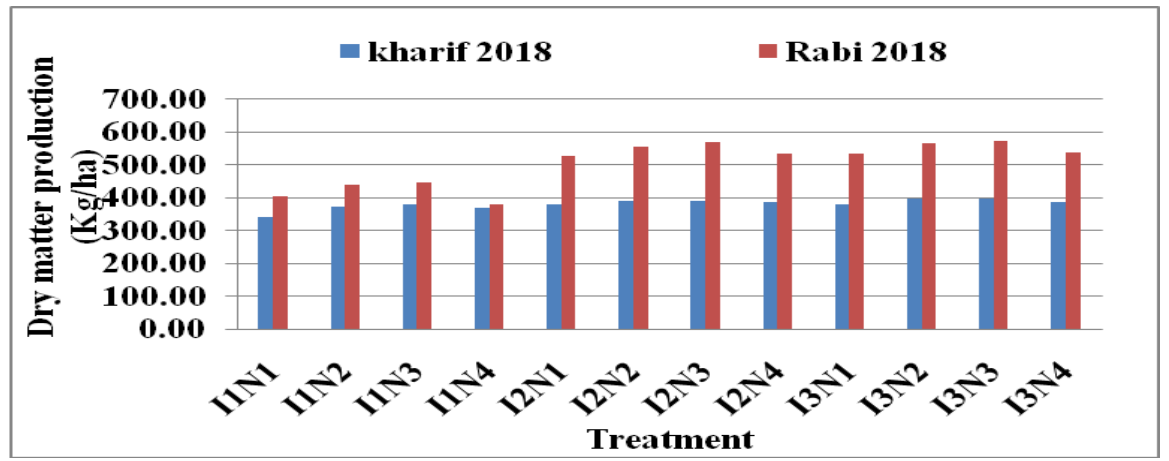

Fig.2 Treatment wise nitrogen use efficiency for crop seasons

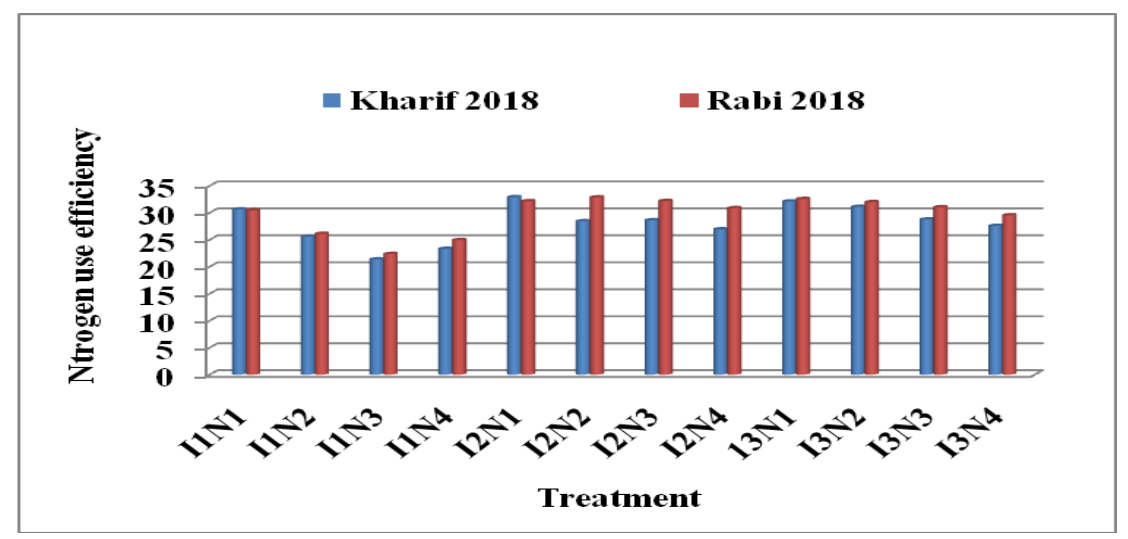

\section{Nitrogen use efficiency of maize crop}

The data on nitrogen use efficiency of maize under drip irrigation for two seasons are furnished in the Table 9 and depicted in Fig 2. NUE varied due to irrigation regimes as well as fertilizer levels. The highest NUE of 32.88 $\mathrm{kg} \mathrm{ha}^{-1} \mathrm{~mm}^{-1}$ was obtained in, $\mathrm{I}_{2} \mathrm{~N}_{1}$ treatment during kharif 2018. During rabi 2018-19 the highest NUE of $32.85 \mathrm{~kg} \mathrm{ha}^{-1} \mathrm{~mm}^{-1}$ was in $\mathrm{I}_{2} \mathrm{~N}_{2}$. The lowest NUE of 21.35 and $22.36 \mathrm{~kg}$ $\mathrm{ha}^{-1} \mathrm{~mm}^{-1}$ was obtained in $\mathrm{I}_{1} \mathrm{~N}_{3}$ treatment during kharif 2018 and rabi 2018-19.The analysis of variance to compare the means of NUE (Table 10) for main, sub and main Vs sub treatments showed that there is a significant difference between irrigation levels $(\mathrm{P}=0.000)$ for kharif 2018 and rabi 2018-19 respectively.
The Duncan test for comparing treatment means of NUE showed that all the treatments for main plots (Irrigation levels) (Table $11 \& 13)$ and sub plots (Nitrogen levels) (Table $12 \& 14)$ have significant difference during kharif 2018 and rabi 2018-19 respectively.

Nutrients may be used very effectively when applied continuously through the irrigation system at rates not exceeding the requirements of the plants, which is in agreement with the results obtained earlier by Bar-Yosef and Sagiv, 1982; Miller et al., 1981; Phene et al., 1979 and Stark et al., 1983.

Availability of adequate and optimum moisture under 0.8 ETc resulted in higher nutrient use efficiency and even with 1.0 Etc also. This proves the efficiency of drip 
fertigation system. Lower fertilizer dose (80 per cent RDN) through drip fertigation with greater nutrient use efficiencies was in line with the findings of Raman (1995); Singh et al., (1989); Dangler and Locascio, (1990); Goyal et al., (1985). Nitrogen uptake increased with $\mathrm{N}$ rate, but it is obvious that NUE decreased with increasing the $\mathrm{N}$ rate (Thompson and Doerge, 1996b; Stark et al., 1983; Iqbal et al., 2003).

In conclusion the drip fertigation led to a higher dry matter production with $\mathrm{I}_{3} \mathrm{~N}_{3}$ treatment in both kharif 2018 and rabi 201819 seasons and higher NUE was obtained at $\mathrm{I}_{2} \mathrm{~N}_{1}$ treatment during kharif 2018 season and $\mathrm{I}_{2} \mathrm{~N}_{2}$ treatment in rabi 2018-19 season at coastal Andhra Pradesh. This results shows that the drip fertigation makes effective utilization of nitrogen under drip fertigated maize crop.

\section{Application of research}

This article has been prepared with the objective of giving information to the maize growers on dry matter production and nitrogen use efficiency in coastal region of Andhra Pradesh. The investigations of the research used for the purpose of proper planning of irrigation and fertigation schedule to achieve high nutrient use efficiency.

\section{Abbreviations}

$\mathrm{mm}-$ Millimeter, $\mathrm{CF}-$ Conventional Fertilizer, DMP - dry matter production, CROPWAT - Crop water requirement, SPSS - Statistical Package for the Social Sciences, ANOVA - Analysis Of Variance, DMRT Duncan Multiple Range Test, NUE - Nutrient Use Efficiency.

\section{Acknowledgement}

I would like to express my special thanks of gratitude to my chairman Dr. A. Mani who gave me the golden opportunity to do this wonderful project. I also thank to the Department of Soil and Water Engineering, Dr. N. T. R. College of Agricultural Engineering, Bapatla for the resources provided me to carry the field experiment.

\section{References}

Agricultural Statistics at a Glance (2018). Government of India, Ministry of Agriculture \& Farmers Welfare Department of Agriculture, Cooperation \& Farmers Welfare, Directorate of Economics and Statistics.

Palm, C.A., Rowland, A.P. 1997. Chemical characterization of plant quality for decomposition. Journal of Agriculture, Ecosystems and Environment 83:27-42.

Mugendi, D.N., James Kung, J., Mugwe, J and Bationo, A. 2007. Effects of organic and mineral fertilizer inputs on maize yield and soil chemical properties in a maize cropping system in Meru South District, Kenya. Journal of Agroforest Systems. 69:189-197.

Mucheru-Muna, M. W., Mugendi, D., Pypers, P., Kungu, J., Mugwe, J., Kung, J., Vanlauwe, B. and mERCKX, B. 2014. Enhancing maize productivity and profitability using organic inputs and mineral fertilizer in central kenya smallhold farms. Journal of Experimental Agriculture. volume 50 (2): 250-269.

Rajasekaran, M. 2007. Effect of drip fertigation on growth, yield and quality of tropical sugarbeet. M.Sc., (Ag.), Thesis, Tamil Nadu Agricultural University, Coimbatore.

Bar-Yosef B, B. Sagiv and T. Markovitch. 1989. Sweet corn response to surface and subsurface trickle phosphorous fertigation. Jouranl of Agronomy.Vol. 81: 443-447. 
Vadivel, N., P. Subbian and A. Velayutham. 2001. Effect of integrated nitrogen management practices on the growth and yield of rainfed winter maize (Zea mays). Indian Journal of Agronomy. 46(2): 250-254.

Patel, J.B., Patel, J.R. 2006. Influence of different methods of irrigation and nitrogen levels on crop growth rate and yield of maize (Zea mays L.). Indian Journal of crop science. 1 (1\&2): 175177.

Bindhani, A., Barik, K.C., Garnayak, L.M and Mahapatra, P. K. 2008. Productivity and nitrogen use efficiency of baby conr (Zea mays L.) at different levels and timing of nitrogen application under rainfed condition. Indian Journal of Agricultural science. 78 (7): 629-631.

Ganasaraja, V., Rani, S., Kavitha, M.P and Paulpandi, V.K. 2009. Effect of drip irrigation regimes and fertilizer application methods on growth, yield and nutrient uptake of baby corn. Journal of Maharastra Agricultural Universities. 34 (1):92-93.

Muthurakrishnan, $\mathrm{P}$ and $\mathrm{S}$ Anitta Fanish 2011. Influence of drip Fertigation on yield water saving and WUE in maize. Madras agriculture Journal. 98(7-9): 243-247.

Bibe, S.M., Jadhav, K.T and Chavan, A.S. 2017. Response of irrigation and fertigation management on growth and yield of maize. International Journal of
Current Microbiology and Applied Sciences. 6 (11): 4054 - 4060.

Bar-Yosef, B. and B. Sagiv. 1982. Response of tomatoes to $\mathrm{N}$ and water applied via trickle irrigation system. I. Nitrogen. Agronomy Journal. Vol (74): 633-637.

Miller, R.J., D.E. Rolston, R.S. Raushkolb and D.W. Wolfe. 1981. Labelled nitrogen uptake by drip-irrigated tomatoes. Agronomy Journal.Vol (73): 265-270.

Stark, J.C., W.M. Jarrell, J. Letey and N. Valoras. 1983. Nitrogen use efficiency of trickleirrigated tomatoes receiving continuous injection of N. Agronomy Journal. Vol(75): 672-676.

Singh, S.D., Y.V. Singh and R.C. Bhandari. 1989. Tomato yield as related to drip lateral spacing and fertilizer application on total and wetted area basis. Canadian Journal of Plant sciences. 63(3): 991-999.

Goyal, M.R., L.E. Rivera and C.L. Santiago, 1985. Nitrogen fertigation in drip irrigated peppers, tomatoes and eggplant, In: Drip/Trickle Congress by ASAE, Fresno, CA. Nov. 16-20. Vol. I, Paper I-10. p. 388-92.

Iqbal, Z., A.l. Latif, S. Ali and M. Mohsin Iqbal. 2003. Effect of fertigated phosphorus on $\mathrm{P}$ use efficiency and yield of wheat and maize. Songklanakarin Journal of Science and Technology. 25(6): 697-702.

\section{How to cite this article:}

Raja Kumar, A. Mani, G. Ravi Babu, M. Martin Luther and Sujani Rao, CH. 2021. Effect of Drip Fertigation on Dry Matter Production and Nitrogen Use Efficiency of Maize (Zea mays). Int.J.Curr.Microbiol.App.Sci. 10(01): 3212-3222. doi: https://doi.org/10.20546/ijcmas.2021.1001.374 